\title{
Current Activities to Implement Integrated Teaching Learning in Undergraduate Medical Education in Bangladesh: Students' View
}

\author{
Tapu $\mathrm{TT}^{1}$, Talukder $\mathrm{HK}^{2}$, Talukder MAS ${ }^{3}$, Flora $\mathrm{TA}^{4}, \mathrm{Ahmad} \mathrm{KT}^{5}$
}

\begin{abstract}
:
The present study was conducted amongst students of all phases in eight medical colleges (4 govt. \& 4 non-govt.) of Bangladesh to assess views of students about the current activities to implement integrated teaching learning in undergraduate medical education in Bangladesh. Among 956 students, 387(40.5\%) were male and 569(59.5\%) were female. This study revealed that $605(63.3 \%)$ students had participated in integrated teaching learning session, 328(54.3\%) students disagreed that the subjects of different phases are arranged sequentially in curriculum and 265(43.8\%) students responded that integrated sessions were conducted in large group sessions. More than half of the students $(53.7 \%)$ stated that integrated teaching helped them to get better understanding of the topic and integrated teaching also helped them to improve application of knowledge. Insufficiency of infrastructure, allocated time, teachers' training have been identified by respondents as barriers for implementing integrated teaching learning. Study recommended more awareness and training of teachers and students regarding integrated teaching learning. Study also recommended to choose contents which have much clinical importance for integrated teaching and which have been taught repeatedly in different departments.
\end{abstract}

Key words: Integrated Teaching Learning, Undergraduate Medical Education.

1. Tapu TT, Lecturer (Education Science), Centre for Medical Education (CME), Dhaka, Bangladesh.

2. Talukder HK, Professor (Curriculum Development \& Evaluation), Centre for Medical Education (CME), Dhaka, Bangladesh.

3. Talukder MAS, Lecturer (Education Science), Centre for Medical Education (CME), Dhaka, Bangladesh.

4. Flora TA, Resident MS(Histopathology), SSMC, Dhaka, Bangladesh.

5. Ahmad KT, Clinical staff (Emergency Medicine), Square Hospital Limited, Dhaka, Bangladesh.

Address of correspondence: Dr. Thanadar Tamjeeda Tapu, Lecturer (Education Science), Centre for Medical Education (CME), Dhaka, Bangladesh

\section{Introduction}

The medical curriculum is vast and students are expected to learn many subjects at the same time. The teachers are also involved in a number of activities apart from teaching like research, administrative, updating their knowledge etc. In doing so, teaching undergraduate medical students frequently remains a separate academic department without integration to interrelate or unify subjects. Hence current medical education imparts knowledge in a disjointed manner and does not allow students to develop the skills to investigate, analyze and prepare to perceive the patient as a whole 1 There is a need to teach the students by correlating the various subjects

Bangladesh Journal of Medical Education 2020; 11(1);Tapu et al., publisher and licensee Association for Medical Education. This is an Open Access article which permits unrestricted non-commercial use, provided the original work is properly cited. 
to create interest and promote active learning. This can be achieved by teaching the same topic in sequence manner from different faculty members of different departments. Medical education all over the world recognizes that the integration in medical education is one of the major education reforms required..$^{2}$ Integration as defined by Harden is "the organization of teaching matter to interrelate or unify subjects frequently taught in separate academic courses or departments". 3 Integrated curricula have been implemented in medical education in developed and developing countries. In their implementation of integration, most schools follow an organ system or an approach based on clinical conditions. However, improving and strengthening integration is always a challenge. ${ }^{4}$ Since 2002, integration was introduced in curriculum to ensure the harmonious functioning of the educational processes. But the status of effective implementation of integrated teaching learning is yet not sorted out by any study. The aim of this study was to find out students' view regarding current activities to implement integrated teaching learning in undergraduate medical education.

\section{Methods and Materials}

It was a cross sectional descriptive study. Study period was from July 2018 to June 2019. The study places were four government and four non-government medical colleges of Bangladesh. Undergraduate medical students of all four phases of the selected medical colleges were the study population. Sample size was 956 medical students. A self-administered semi-structured questionnaire was prepared for data collection. Questionnaires were distributed amongst the students and data were collected from the students at end of the lecture classes. Medical colleges and students were selected conveniently. After collection, data were checked and then entered into the software of the computer for analysis. SPSS program (IBM SPSS statistics 19) was used for data analysis. Likert scale was used to measure responses.

\section{Results}

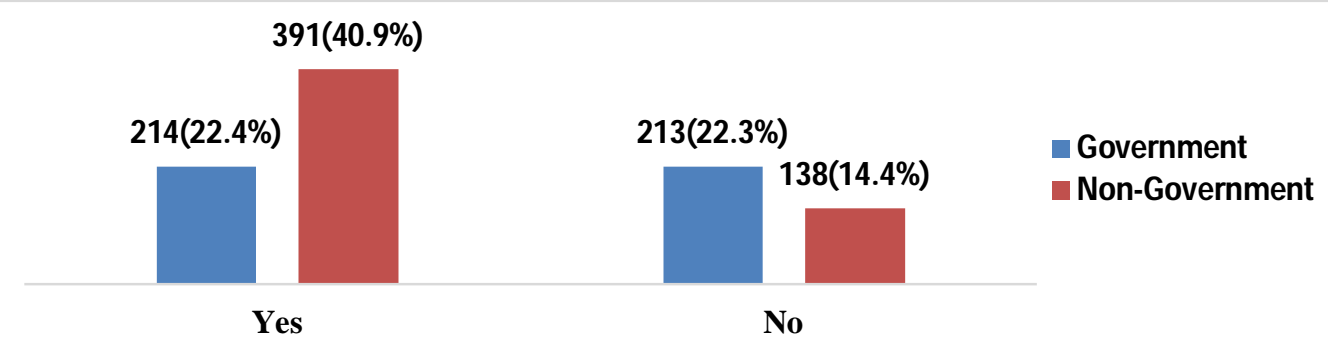

Figure 1 Distribution of students by their participation in integrated session and types of Institution $(n=956)$

Figure 1 multiple bar diagram shows that out of 956 students, 214 students from Government medical colleges and 391 from Non-government medical colleges had participated in integrated teaching learning session, the remaining had not participated in any integrated teaching learning session.

Bangladesh Journal of Medical Education 2020; 11(1);Tapu et al., publisher and licensee Association for M edical Education. This is an Open Access article which permits unrestricted non-commercial use, provided the original work is properly cited. 
Table 1 Distribution of the respondents regarding the benefit of integrated teaching learning in undergraduate medical education

\begin{tabular}{|l|c|c|c|c|c|}
\hline \multicolumn{1}{|c|}{$\begin{array}{c}\text { Statements regarding the benefit of integrated } \\
\text { teaching learning }\end{array}$} & \multicolumn{5}{|c|}{ Level of agreement } \\
\cline { 2 - 6 } & $\begin{array}{c}\text { SDA } \\
\text { f(\%) }\end{array}$ & $\begin{array}{c}\text { DA } \\
\text { f(\%) }\end{array}$ & $\begin{array}{c}\text { NAND } \\
\text { f(\%) }\end{array}$ & $\begin{array}{c}\text { A } \\
\text { f(\%) }\end{array}$ & $\begin{array}{c}\text { SA } \\
\text { f(\%) }\end{array}$ \\
\hline $\begin{array}{l}\text { Integrated teaching helped me to get better } \\
\text { understanding of topic }\end{array}$ & 86 & 119 & 236 & 380 & 133 \\
\hline $\begin{array}{l}\text { Integrated teaching helped me to improves } \\
\text { application of knowledge }\end{array}$ & $(9.0)$ & $(12.5)$ & $(24.7)$ & $(39.8)$ & $(13.9)$ \\
\hline
\end{tabular}

Table 1 shows out of total 954 students, 380(39.8\%) agreed and 133(13.9\%) strongly agreed that integrated teaching helped them to get better understanding of topic, out of 953 students, 402(42.2\%) agreed and 137(14.4\%) strongly agreed that integrated teaching helped them to improve application of knowledge.

Table 2 Distribution of the respondents regarding the activities to implement integrated teaching learning in undergraduate medical education

\begin{tabular}{|c|c|c|c|c|c|}
\hline \multirow[t]{2}{*}{ Statements } & \multicolumn{5}{|c|}{ Level of agreement } \\
\hline & $\begin{array}{l}\text { SDA } \\
\text { f(\%) }\end{array}$ & $\begin{array}{c}\text { DA } \\
\mathbf{f}(\%)\end{array}$ & $\begin{array}{c}\text { NAND } \\
\text { f(\%) }\end{array}$ & $\begin{array}{c}\mathbf{A} \\
\mathbf{f}(\%)\end{array}$ & $\begin{array}{c}\text { SA } \\
\mathbf{f}(\%)\end{array}$ \\
\hline $\begin{array}{l}\text { The subjects of different phases are arranged } \\
\text { sequentially in curriculum }\end{array}$ & $\begin{array}{c}226 \\
(37.4) \\
\end{array}$ & $\begin{array}{c}102 \\
(16.9) \\
\end{array}$ & $\begin{array}{c}106 \\
(17.5)\end{array}$ & $\begin{array}{l}139 \\
(23) \\
\end{array}$ & $\begin{array}{c}32 \\
(5.3) \\
\end{array}$ \\
\hline $\begin{array}{l}\text { Integrated sessions are conducted in large group } \\
\text { sessions }\end{array}$ & $\begin{array}{c}73 \\
(12.1)\end{array}$ & $\begin{array}{c}131 \\
(21.7)\end{array}$ & $\begin{array}{c}136 \\
(22.5)\end{array}$ & $\begin{array}{c}196 \\
(32.4)\end{array}$ & $\begin{array}{c}69 \\
(11.4)\end{array}$ \\
\hline $\begin{array}{l}\text { Integrated sessions are conducted in small group } \\
\text { sessions }\end{array}$ & $\begin{array}{c}67 \\
(11.1)\end{array}$ & $\begin{array}{c}140 \\
(23.3)\end{array}$ & $\begin{array}{c}172 \\
(28.6)\end{array}$ & $\begin{array}{c}172 \\
(28.6)\end{array}$ & $\begin{array}{c}51 \\
(8.5)\end{array}$ \\
\hline $\begin{array}{l}\text { Power point presentation is used for integrated } \\
\text { session }\end{array}$ & $\begin{array}{c}64 \\
(10.6) \\
\end{array}$ & $\begin{array}{c}97 \\
(16.0) \\
\end{array}$ & $\begin{array}{c}137 \\
(22.6) \\
\end{array}$ & $\begin{array}{c}214 \\
(35.4) \\
\end{array}$ & $\begin{array}{c}93 \\
(15.4) \\
\end{array}$ \\
\hline $\begin{array}{l}\text { Black board/white board is used in integrated } \\
\text { sessions }\end{array}$ & $\begin{array}{c}72 \\
(11.9)\end{array}$ & $\begin{array}{c}130 \\
(21.5)\end{array}$ & $\begin{array}{c}146 \\
(24.2)\end{array}$ & $\begin{array}{c}203 \\
(33.6)\end{array}$ & $\begin{array}{c}53 \\
(8.8)\end{array}$ \\
\hline $\begin{array}{l}\text { Real/simulated patient is used in integrated } \\
\text { sessions }\end{array}$ & $\begin{array}{c}83 \\
(13.7)\end{array}$ & $\begin{array}{c}122 \\
(20.2)\end{array}$ & $\begin{array}{c}146 \\
(24.1)\end{array}$ & $\begin{array}{c}182 \\
(30.1)\end{array}$ & $\begin{array}{c}72 \\
(11.9)\end{array}$ \\
\hline Mostly lecturers conduct integrated sessions & $\begin{array}{c}70 \\
(11.6) \\
\end{array}$ & $\begin{array}{c}106 \\
(17.6) \\
\end{array}$ & $\begin{array}{c}150 \\
(24.9) \\
\end{array}$ & $\begin{array}{c}214 \\
(35.5) \\
\end{array}$ & $\begin{array}{c}63 \\
(10.4) \\
\end{array}$ \\
\hline $\begin{array}{l}\text { Mostly senior teachers conduct integrated } \\
\text { sessions }\end{array}$ & $\begin{array}{c}64 \\
(10.6) \\
\end{array}$ & $\begin{array}{c}86 \\
(14.2) \\
\end{array}$ & $\begin{array}{c}138 \\
(22.8) \\
\end{array}$ & $\begin{array}{c}219 \\
(36.2) \\
\end{array}$ & $\begin{array}{c}98 \\
(16.2) \\
\end{array}$ \\
\hline
\end{tabular}

Table 2 shows among the 605 students, who had participated in integrated teaching learning session, $102(16.9 \%)$ disagreed and 226(37.4\%) strongly disagreed that the subjects of different phases were arranged sequentially in curriculum, 196(32.4\%) agreed and 69(11.4\%) strongly agreed that integrated sessions were conducted in large group sessions.

Bangladesh Journal of Medical Education 2020; 11(1);Tapu et al., publisher and licensee Association for M edical Education. This is an Open Access article which permits unrestricted non-commercial use, provided the original work is properly cited. 
Figure 2 Distribution of the respondent regarding barriers of integrated teaching learning in undergraduate medical education

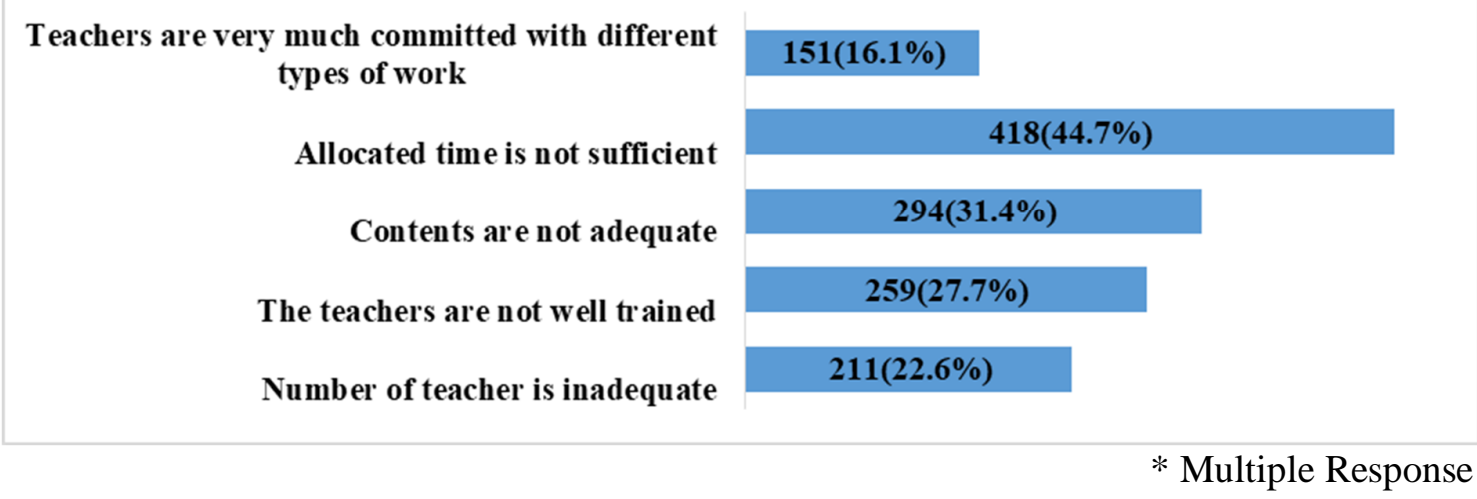

Figure 2 shows, regarding barriers of integrated teaching learning in undergraduate medical education $418(44.7 \%$ ) responses were in favour of allocated time is not sufficient, $259(27.7 \%)$ were in favour of the teachers are not well trained. Other statements also responded by students in significant proportion as depicted in above figure.

\section{Discussion}

Curriculum integration can be described as an approach of teaching and learning that is based on both philosophy and practicality. It can generally be defined as a curriculum approach that purposefully draws together knowledge, skills, attitudes and values from within or across subject areas to develop a more powerful understanding of key ideas. Curriculum integration occurs when components of the curriculum are connected and related in meaningful ways by both the students and teachers. ${ }^{5}$ Integration has successfully been implemented in many medical programs with convincing evidence of improved learning outcomes in medical students. ${ }^{6}$ About $75 \%$ students opined that integrated teaching sessions helped them in a better understanding of topic, many opined it would help them in application of knowledge in clinical aspects. ${ }^{7}$ Similar result was found in present study where around $55 \%$ of students stated that integrated teaching helped them to get better understanding of topic and helped them to improve application of knowledge (Table 1). The learning by integrated teaching had potential to improve the knowledge, skills, and comprehensive learning, the students found it exhaustive If the planning and implication of integrated teaching are done properly, it may lead to better learning outcomes. This might be useful to improve their prescription skills and to be a better-qualified health professional. ${ }^{8}$ In this study around 55\% students opined against the statement that the subjects of different phases are arranged sequentially in curriculum (Table 2). Same type of result was revealed by another study where about $90 \%$ teachers passed opinion for rearrangement of subjects of 2nd and 3rd phase. ${ }^{9}$ Amongst different method used, 34\% students believed that Bangladesh Journal of Medical Education 2020; 11(1);Tapu et al., publisher and licensee Association for M edical Education. This is an Open Access article which permits unrestricted non-commercial use, provided the original work is properly cited. 
demonstrations are a very good method for integrated learning sessions while only $11 \%$ rated didactic lecture as a very good method for the same. ${ }^{10}$ Similar results were shown in another study. ${ }^{11}$ Similar results were seen in a study, which was carried out to assess student ${ }^{\text {ee }}$ perception of effective small group teaching in a medical college" at McGill University in Canada. ${ }^{\mathbf{1 2}}$ But the present study revealed that about $45 \%$ students responded that integrated sessions were conducted in large group sessions (Table 2). About 50\% students (Table 2) opined that only power point presentation was used for integrated sessions. In the open ended part of the questionnaire for students, one student told that "Teachers only show us slides prepared early which is a boring thing, we get no interest." Teachers need to put more efforts to make it more interesting and interactive and hence that students should not lose interest during integrated teaching sessions. ${ }^{8}$ Implementation of integration in a curriculum is a demanding task for medical education. It requires effective leadership, collaboration of faculty members, administration and students.

\section{Conclusion}

The participants in the study responded positively towards different issues related to integrated teaching. Most important to all, it is hoped that the study could raise the awareness about integrated teaching learning. Integrated teaching could be more effective if teachers were well trained and with more students' participation. It holds much promise for raising students, who will be able to apply their knowledge to the real world.

\section{References:}

1. Kate MS, Kukarni UJ, Supe A, Deshmukh YA: Intoducing Integrated Teaching in Undergraduate Medical Curriculum. International Journal of Pharma Sciences \& Research (IJPSR); 2010. vol.1(1):18-22.

2. Muthukumar T, Konduru1 $\mathrm{R} \mathrm{K}$, Manikandan M, Asir J, Iqbal N, Bazroy J, PurtyA J, Singh Z: Scope of integrated teaching in a medical college: A study from South India, 2017.Retrieved September 13, 2018, from: http://www.jmedsoc.org

3. Harden RM, Sowden S, Dunn WR: Educational strategies in curriculum development: The SPICES model. Medical Education, 1984; 18,284-297.

4. Shankar PR, Balasubramanium R, Dwivedi NR, Nuguri V: Student feedback about the integrated curriculum in a Caribbean medical school, Aruba. J Educ Eval Health, 2014.Retrieved from: Prof.2014;11.23.http://dx.doi.org/10.33 52/jeehp.2014.11.9.

5. Alberta Education Guide: Primary Programs Framework Curriculum Integration: Making Connections. Alberta Education, Alberta, Canada, 2007.

6. Van der Veken J, Valcke M, De Maeseneer J, Schuwirth L, Derese A: Impact on knowledge acquisition of the transition from a conventional to an integrated contextual medical curriculum. Med Educ, 2009; 43(7): 704-13.

7. Yadav P P, Chaudhury M, Patel J, Shah A, Kantharia N D: Effectiveness of

Bangladesh Journal of Medical Education 2020; 11(1);Tapu et al., publisher and licensee Association for M edical Education. This is an Open Access article which permits unrestricted non-commercial use, provided the original work is properly cited. 
integrated teaching module in pharmacology among medical graduates, International Journal of Applied and Basic Medical Research, 2016;6(3):215-219.

8. Ambwani S, Vegada B, Sidhu R and Charan J:Impact of Integrated Teaching Sessions for Comprehensive Learning and Rational Pharmacotherapeutics for Medical Undergraduates. International Journal of Applied and Basic Medical Research, 2017; S57-S61.

9. Rahman M:Views of Teachers' and Students' Regarding Curriculum for Under-graduate Medical Education in Bangladesh-Updated 2012, 2018.
10.Bhardwaj P, Bhardwaj N, Mahdi F, Srivastava J P, Gupta U:Integrated teaching program using case based learning .International Journal of Applied and Basic Medical Research,2015.

11. Ghosh S, Pandya H: Implementation of Integrated Learning Program in neurosciences during first year of traditional medical course: Perception of students and faculty. BMC Medical Education, 2008;8:44.

12.Steinert Y:Student' perception of effective small group teaching. Medical Education, 2004;38:286-93.

Bangladesh Journal of Medical Education 2020; 11(1);Tapu et al., publisher and licensee Association for M edical Education. This is an Open Access article which permits unrestricted non-commercial use, provided the original work is properly cited. 